“iş, Güç” Endüstri İlişkileri ve İnsan Kaynakları Dergisi

Cilt:9 Sayı:1, Ocak 2007, ISSN: 1303-2860

“İs, Güç" The Journal of Industrial Relations and Human Resources

Vol:9 No:1 January 2007, ISSN: 1303-2860

WORKAHOLISM, WORK AND EXTRA-WORK

SATISFACTIONS, AND PSYCHOLOGICAL WELL-

BEING AMONG PROFESSORS IN TURKEY ${ }^{1}$

\author{
RONALD J. BURKE \\ York University / Canada \\ MUSTAFA KOYUNCU \\ Ericeyes Universitesi / Turkey \\ LISA FIKSENBAUM \\ York University / Canada
}

\title{
ABSTRACT
}

Purpose - This research examined the relationship of three workaholism components identified by Spence and Robbins (1992) and work, extra-work and psychological health outcomes.

Design/Methodology/Approach - Data were collected from 406 professors in Turkey (243 males and 165 females) using an internet-based survey. Measures included personal and situational characteristics, possible workaholism antecedents (beliefs and fears, organizational values supporting work personal life imbalance), workaholism components (work enjoyment, feeling driven to work, and work involvement), validating job behaviors (perfectionism, stress), work outcomes (job and career satisfaction), extra-work outcomes (e.g., family satisfaction) and psychological health (e.g., psychosomatic symptoms).

Findings - Workaholism components, particularly work enjoyment and feeling driven to work because of inner pressures, emerged as strong and consistent predictors of a number of work and well-being outcomes.

1 This research was supported in part by the Schulich School of Business, York University and Erciyes University. Louise Coutu prepared the manuscript. We thank Janet Spence for making her measures available to us. 
Practical implications - Work enjoyment emerged as a strong and consistent predictor of most work and well-being outcomes. Organizations are encouraged to increase satisfaction levels in efforts to attain productive and healthy people.

Originality/value. Replicates previous North American workaholism research in Turkey.

Key Words: Workaholism, Professors, Turkey, work satisfaction, psychological well-being.

\section{WORKAHOLISM, WORK AND EXTRA-WORK SATISFACTIONS, AND PSYCHOLOGICAL WELL-BEING AMONG PROFESSORS IN TURKEY}

Although the popular press has paid considerable attention to workaholism (Fassel, 1990; Garfield, 1987; Kiechel, 1989 a,b; Killinger, 1991; Klaft \& Kleiner, 1988; Machlowitz, 1980; Spruel, 1987; Waddell, 1993), relatively little research has been undertaken to further our understanding of it. It should come as no surprise then that opinions, observations, and conclusions about workaholism are both varied and conflicting (Harpaz \& Snir, 2003). Some writers view workaholism positively from an organizational perspective (Korn, Pratt \& Lambrou, 1987; Machlowitz, 1980; Sprankle \& Ebel, 1987). Machlowitz (1980) conducted a qualitative interview study of 100 workaholics and found them to be both satisfied and productive. Others view workaholism negatively (Killinger, 1991; Schaef \& Fassel, 1988; Robinson, 1998; Oates, 1971). These writers equate workaholism with other addictions, and depict workaholics as unhappy, obsessive, tragic figures who are not performing their jobs well and are creating difficulties for their coworkers (Naughton, 1987; Oates, 1971; Porter, 1996). The former might advocate the encouragement of workaholism; the latter would discourage it.

A compelling case could be made for devoting more research attention to workaholism. There has also been suggestions that workaholism may be increasing in North America (Schor, 1991; 2003; Fassel, 1990). In addition it is not clear whether workaholism has positive or negative organizational consequences (Machlowitz, 1980; Killinger, 1991). There is also debate on the association of workaholic behaviors with a variety of personal well-being indicators such as psychological and physical health and self-esteem (McMillan, O'Driscoll 
\& Burke, 2003). Finally, different types of workaholic behavior patterns likely exist, each having unique antecedents and outcomes (Naughton, 1987; Scott, Moore \& Miceli, 1991). The question of whether and how workaholism can, or should be reduced, had also been raised (Porter, 1996; Killinger, 1991; Seybold \& Salomone, 1994).

The present study of workaholic job behavior builds on previous research as well as extends this work to new areas. A decision was made to use the definition of workaholism put forward by Spence and Robbins (1992) and their measures. Spence and Robbins (1992) defined the workaholic as "a person who is highly work involved, feels compelled or driven to work because of inner pressures, and is low in enjoyment at work@ (p.62). This research considers potential consequences of workaholic behaviors. More specifically, this study examines the role workaholism plays in work and extra-work satisfactions and psychological well-being, (see Figure 1). Four groups of predictor variables were included: individual demographic characteristics, work situation characteristics, individual and organizational antecedents of workaholism, and workaholism components. Individual demographic characteristics included age, gender and marital status. Work situation characteristics included organizational size and tenure in present job. Two additional antecedents of workaholism were also considered (see Burke, 1999, 2001). One, an individual difference measure tapped personal beliefs and fears, a measure of attitudes, values and orientation towards one's broader environment (Lee, Jamieson \& Earley, 1996). This measure has been found to predict levels of Type $A$ behavior and aspects of performance (Lee, et. al. 1996). Robinson (1998) reports a significant positive correlation between his measure of workaholism and a commonly used measure of Type A behaviour. The second, an organizational level measure, assessed perceptions of organizational support of work-personal life balance or imbalance (Kofodimos, 1993). The fourth block of predictor variables were three workaholism components identified by Spence and Robbins (1992). Criterion variables included a wide range suggested in the literature (see Burke, 2000a) to be affected by workaholism (e.g. job and career satisfaction, intent to quit, psychological well-being).

\section{Click here to see Figure 1}


A study of workaholism among professors in Turkey was undertaken. The initial Spence and Robbins (1992) research involved university professors of Social Work, in the United States, and professors have been found to both work long hours and report considerable job satisfaction. Although only Spence and Robbins have studied workaholism among professors, professors have been included in more traditional work stress research.

This research has considered the relationship of work and family stress and various work, family and health outcomes (Grandy \& Cropanzano, 1999), Type A behavior stress and research productivity (Frei, Racico \& Travagline, 1998), stressful incidents at work (Narryanan, Menon \& Spector, 1999), the stress experienced by academic department chairs (Gmelch \& Burns, 1994) and gender differences in work-related stress and burnout (Doyle \& Hind, 1998). In addition to these studies of work experiences and health of professors, several researchers have studied gender differences among professors. These have examined salary (Ashraf, 1996; Gander, 1997; Ginther \& Hayes, 1999), career development and advancement (McDowell, Singell \& Ziliak, 1999; Ozbilgin \& Healy, 2004); levels of job stress (Adeoye, 1991) and job satisfaction (Oshagbemi, 2000; Smith \& Plant, 1982).

Although the early workaholism studies were conducted in North America (e.g., Burke, 1999; Bonebright, Clay \& Aikenmann, 2000; Robinson, 1998; Porter, 2001) research on workaholism has been conducted in the Netherlands (Buelens \& Poelmans, 2004; Schaufeli, Taris \& Bakker, 2006; Taris, Schaufeli \& Verhoeven, 2004), Israel (Snir \& Harpaz, 2004) New Zealand (McMillan \& O'Driscoll, 2004; McMillan, O'Driscoll \& Brady, 2004), Japan (Kanai, Wakabayashi \& Fling, 1996; Kanai \& Wakabayashi, 2004), Norway (Burke, Richardsen \& Martinussen, 2004; Burke \& Mattheisen, 2004) and Australia (Russo \& Waters, 2006; Burke, Burgess \& Oberklaid, 2002). The present research carried out in Turkey, reflects an emerging and needed international interest in the topic.

\section{Method}

\section{Respondents}

Data were collected from 406 professors in Turkey using anonymously completed questionnaires. Table 1 shows the demographic characteristics of this sample. The sample comprised 
more men than women $(60 \%$ and $40 \%$ respectively), were married $(52 \%)$, had one or two children (50\%), were almost evenly split with half being under 35 years of age and half over 35, about half had steady fulltime jobs while half worked on contract, most were in lower level professorial jobs (39\%, as lecturers), most had worked continuously since completing their education (85\%), most had worked full-time $(73 \%)$ about one third had some administrative responsibilities (38\%), almost half $(46 \%)$ taught 16 or more hours per week, most had relatively short job and university tenure $(66 \%$ had 5 or fewer years of job tenure while $40 \%$ had 5 or fewer years of organization tenure). Finally, the majority of professors earned $\$ 1000$ US per month or less (75\% in $2003,68 \%$ in 2004$)$.

\section{Click here to see Table 1}

\section{Procedure}

The survey was sent as a web page link to 10 universities selected from each of the seven geographical regions in Turkey. Surveys were sent to all academics in every department at these universities. A total of 406 completed questionnaires were returned, representing about a forty percent response rate.

\section{Measures}

All measures were translated from English to Turkish using the back translation method.

\section{Personal Characteristics}

Five individual demographic characteristics measured by single items were included; age, sex, marital status, parental status and number of children.

\section{Work Situation Characteristics}

Seven work situation characteristics measured by single items were included: organizational level, years in present position, years with present university, university size, had ever worked part time, had taken a break in their careers, and currently had administrative duties. 


\section{Workaholism Antecedents}

\section{Beliefs and Fears}

Three measures of beliefs and fears developed by Lee, Jamieson and Early (1996) were used. One, Striving against others .( $=.87$ ), had six items (e.g. "There can only be one winner in any situation"). A second, No moral principles (=.65), had six items (e.g., "I think that nice guys finish last"). The third, Prove yourself $(=.87)$, had nine items (e.g., "I worry a great deal about what others think of me"). Responses were made on a five-point Likert scale $(1=$ Strongly disagree, $3=$ Neither agree nor disagree, $5=$ Strongly agree). A total score was also obtained by combining these three scales $(=.93)$

\section{Organizational Values}

Organizational values encouraging work-personal life balance and imbalance were measured by scales created by Kofodimos (1993). Organizational values encouraging balance was measured by nine items $(\propto=.72)$ (e.g., "Setting limits on hours spent at work"). Organizational values supporting imbalance $(\propto=.71)$ was measured by eight items (e.g.; "Traveling to and from work destinations on weekends"). Responses were made on a five-point Likert scale (1 = very negatively valued, $3=$ neither positively or negatively valued, $5=$ very positively valued). A total balance score was obtained by combining both scales, reversing the imbalance scores.

\section{Workaholism Components}

Spence and Robbins (1992) derived three workaholism components on the basis of an extensive literature review: Work involvement, Feeling driven to work and Work enjoyment. Their measures were used in this study.

Work involvement.$=.47)$ had eight items (e.g. "I get bored and restless on vacations when I haven't anything productive to do").

Feeling driven to work (=.71) had seven items (e.g., "I often feel that there=s something inside me that drives me to work hard").

Work enjoyment.$=.86)$ had ten items (e.g., "My job is more like fun than work"). 


\section{Validating Job Behaviors}

Five measures representing potential behavioral manifestations of workaholism were included.

Job involvement was measured by an eight item scale $(\alpha=.80)$ developed by Spence and Robbins (1992). One item was "I am deeply committed to my job".

Time to job was assessed by seven items $(\alpha=.80)$ developed by Spence and Robbins (1992). An item was "I devote more time to my work than most people".

Job Stress $(\alpha=.76)$ was measured by nine items (e.g., "Sometimes I feel like my work is going to overwhelm me") developed by Spence and Robbins (1992).

Perfectionism ( $\alpha=.86$ ) was measured by eight items (e.g., "I can't let go of projects until I'm sure they are exactly right") developed by Spence and Robbins (1992).

Nondelegation ( $\alpha=.80$ ) was assessed by seven items (e.g., "I feel that if you want something done correctly you should do it yourself") also developed by Spence and Robbins (1992).

\section{Work Outcomes}

Four work outcomes were considered.

Job satisfaction was measured by a seven item scale $(\alpha=.83)$ developed by Kofodimos (1993). An item was "I feel challenged by my work".

Career satisfaction was measured by a five item scale $(\alpha=.84)$ developed by Greenhaus, Parasuraman and Wormley (1990). One item was "I am satisfied with the success I have achieved in my career.

Career prospects was measured by a three item scale $(\alpha=.42)$ developed by Greenhaus, Parasuraman and Wormley (1990). An item was "I expect to advance in my career to senior levels of management".

Intent to Quit ( $\alpha=.75$ ) was measured by two items (e.g., "Are you currently looking for a different job in a different organization?"). This scale had been used previously by Burke (1991). 


\section{Extra-Work Satisfaction}

Three aspects of life or extra-work satisfaction were included.

Family satisfaction was measured by a seven item scale $(\alpha=$ .85) developed by Kofodimos (1993). One item was "I have a good relationship with my family members".

Friends satisfaction was measured by three items $(\alpha=.77)$ developed by Kofodimos (1993). "An item was my friends and I do enjoyable things together".

Community satisfaction was measured by four items $(\alpha=.75)$ also developed by Kofodimos (1993). A sample was "I contribute and give back to my community".

\section{Psychological Well-Being}

Psychosomatic Symptoms was measured by nineteen items $(\alpha=$ .87) developed by Quinn and Shepard (1974). Respondents indicated how often they experienced each physical condition (e.g., headaches) in the past year.

Physical Well-Being was measured by five items $(\alpha=.57)$ developed by Kofodimos (1993). One item was "I participate in a regular exercise program".

Emotional Well-Being was measured by six items $(\alpha=.81)$ developed by Kofodimos (1993). An item was "I actively seek to understand and improve my emotional well-being”.

\section{Results}

\section{Analysis Plan}

Hierarchical regressions were undertaken in which the four blocks of predictor variables were regressed on the various outcome variables (see Figure 1). The first block of predictors included personal demographics $(\mathrm{N}=4)$. The second block included work situation characteristics $(\mathrm{N}=4)$. The third block were the potential workaholism antecedents $(\mathrm{N}=2)$ and the fourth and final block were the workaholism components $(\mathrm{N}=3)$. When a block of predictors accounted for a signiifant amount or incement in explained variance $(p<.05)$. Individual measures within these blocks having independent and significant 
relationships with the outcome variable were identified $(p<.05)$. The first three blocks of predictors served as control variables before examining the relationship of the workaholism components with the various outcome variables.

\section{Predictors of Workaholic Job Behaviors}

Table 2 presents the results of hierarchical regression analyses in which the four blocks of predictors were regressed on five validating workaholic job behaviors. Only one block of predictors accounted for a significant amount or increment in explained variance on Job Involvement: Workaholism components. All three workaholism components had significant and independent relationship with Job Involvement. Professors scoring higher on all three also indicated higher levels of Job Involvement; Work enjoyment $(\beta=.56)$, Feeling driven $(\beta=.29)$ and Work involvement $(\beta=.09)$. Two blocks of predictors accounted for a significant amount or increment in explained variance on Time to job: Workaholism Antecedents and Workaholism Components. Professors more strongly reporting organizational values supporting work-family imbalance devoted more Time to job $(\beta=.09)$ and professors scoring higher on Feeling driven, higher on Work enjoyment and higher on Work involvement devoted more Time to job $\left(\beta_{\mathrm{s}}=.44, .27\right.$ and .18 respectively). Two blocks of predictors accounted for a significant increment in explained variance on Job stress: Workaholism Antecedents and Workaholism Components. Professors scoring higher on Feeling driven and those scoring lower on Work enjoyment reported higher levels of job stress $\left(\beta_{s}=.54\right.$ and -.18 respectively). Both Workaholism Antecendents and Workaholism components accounted for significant increments in explained variance on Perfectionism. Professors reporting organizational values more supportive of work-personal life imbalance indicated greater perfectionism $(\beta=.12)$. Professors scoring higher on Feeling driven and higher on Work enjoyment also indicated greater perfectionism ( $\beta_{\mathrm{s}}$ $=.34$ and .12 , respectively). Only one block of predictors accounted for a significant amount or increment in explained variance on nondelegation: Workaholism Components. Professors scoring higher on Feeling driven also reported more Non-delegation $(\beta=.30)$. 
Neither personal demographic nor work situation characteristics accounted for a significant amount or increment in explained variance on any of the Workaholic job behaviors. Workaholism components on the other hand accounted for a significant increment in explained variance on all five. Feeling driven to work because of inner needs and Work enjoyment had significant and independent relationships with the majority of the validating workaholic job behaviors.

\section{Predictors of Work Outcomes}

Table 3 shows the results of hierarchical regression analyses in which the four blocks of predictors were regressed on four work outcomes: Job satisfaction, career satisfaction, future career prospects and intent to quit. Only one block of predictors accounted for a significant amount or increment in explained variance on the first three work outcomes: Workaholism components. Professors indicating greater work enjoyment also reported greater job satisfaction, career satisfaction and future career prospects $\left(\beta_{\mathrm{s}}=-.24, .40\right.$ and .24 , respectively). Two blocks of predictors accounted for significant increments in explained variance on Intent to quit; personal demographics and Workaholism Antecedents. Professors reporting organizational values more strongly supportive of work-personal life imbalance and professors scoring higher on the measure of Beliefs and Fears indicated greater intentions to quit $\left(\beta_{s}=.26\right.$ and .21 , respectively).

\section{Click here to see Table 3}

\section{Predictors of Extra-Work Satisfactions}

Table 4 shows results of hierarchical regression analyses in which four blocks of predictors were regressed on three measures of extra-work satisfaction: Family, Relationships and Community. One block of predictors accounted for a significant increment in explained variance on Family satisfactions: Workaholism antecedents. Professors scoring lower on the measure of Beliefs and Fears reported more Family satisfaction $\left(\beta_{\mathrm{s}}=.14\right)$. Two blocks of predictors accounted for a significant increment in explained variance on Relationship satisfaction; 
Workaholism Antecedents and Workaholism components. Professors more strongly reporting Organizational values supportive of workpersonal life balance indicated greater Relationship satisfaction ( $\beta=$ .12) and professor reporting greater work enjoyment also indicated greater relationship satisfaction $(\beta=-.16)$. Finally, only one block of predictors accounted for a significant increment in explained variance on Community satisfaction; workaholism components. Professors scoring higher on Work enjoyment also indicated greater community satisfaction $(\beta=.16)$.

Click here to see Table 4

\section{Predictors of Psychological Well-Being}

Table 5 shows the results of hierarchical regression analyses in which four blocks of predictors were regressed on three measures of psychological and physical well-being; Emotional health, Physical health, and Psychosomatic Symptoms. Two blocks of predictors accounted for a significant increment in explained variance on Emotional health: Workaholism Antecedents and Workaholism Components. Professors reporting organizational values more strongly supportive of work-personal life balance, and professors scoring lower on the measure of Beliefs and Fears reported better Emotional health $\left(\beta_{\mathrm{s}}=.16\right.$ and -.12 respectively). Professors indicating higher levels of Work enjoyment also reported better Emotional health $(\beta=.17)$.

Two blocks of predictors accounted for significant increments in explained variance on Physical health: Workaholism Antecedents and Workaholism Components. Professors reporting organizational values more supportive of work-personal life balance reported better Physical health $(\beta=.13)$ and Profesors scoring higher on Work Enjoyment also reported better Physical health $(\beta=.20)$. Finally, two blocks of predictors accounted for significant increments in explained variance on Psychosomatic Symptoms: personal demographics and Workaholism Antecedents. Women reported more psychosomatic symptoms than men $(\beta=-.28)$ and professors scoring higher on the measure of Beliefs and Fears also reported more Psychosomatic Symptoms $(\beta=.17)$.

Click here to see Table 5 


\section{Discussion}

This study attempted to replicate previous research on the antecedents and consequences of workaholism in a sample of professor in Turkey. As such, it has the potential of adding to our understanding of the extent to which previous conclusions can be generalized to professionals in another country and culture.

\section{Consequences of Workaholism Components}

Previous research has shown the workaholism components to be strong predictors of the validating job behaviors and fairly strong predictors of work outcomes, with work enjoyment being the strongest and most consistent predictor, modest and inconsistent predictors of extra-work satisfactions and fairly strong predictors of psychological well being with feeling driven having the strongest (negative) relationship with these indicators.

The findings obtained here were consistent with previous results in some cases but not in others. Consistent findings included the relationship of the workaholism components with the validating job behaviors, the role of work enjoyment in predicting various work outcomes and the role of work enjoyment in predicting extra-work satisfactions. Inconsistent findings were observed in the relationship of the workaholism components and indicators of psychological well-being; work enjoyment emerged as the only predictor of psychological wellbeing among Turkish professors whereas previously Feeling driven to work was found to be the best predictor of these (see Burke, 2000; Kanai, Wakabayashi \& Fling, 1996).

Thus, while the findings reported here were generally in line with previous research, the areas of difference were noteworthy. That is, in this sample, work enjoyment was found to have relationships with almost all outcome measures - work, extra-work, and psychological health. These results suggest that the Spence and Robbins workaholism components may have different relationships with particular outcome measures in different professions in different countries. The present conclusions need to be replicated to determine their generalizability.

\section{Practical Implications}

Job satisfaction has been shown to influence a wide range of individual and organizational outcomes (Locke, 1976). In addition, we 
have considerable understanding of these factors associated with job satisfaction and how to go about improving the workplace to enhance levels of job satisfaction (Katzenbach, 2000; Lawler, 2003). While this was not designed to be a study of job satisfaction of university professors, university administrators would do well to familiarize themselves with this material and in concert, with the professors, identify those areas needing redress.

\section{Limitations of the study}

Some limitations of the study should be noted to put the results in a broader context. First, although the sample was large and the response rate fairly high, it was impossible to determine the representativeness of the sample. Second, all data were based on respondent self-reports raising the possibility of common method variance. Third, a few of the measures had reliabilities below the generally accepted level of .70. Fourth, it is not clear the extent to which these findings generalize to university professor in other countries and cultures. 


\section{REFERENCES}

Adeoye, E. A. (1991) Correlates of job stress among university professors in Nigeria. Nigerian Journal of Guidance and Counseling, 4, 117-126.

Ashraf, J. (1996) The influence of gender on faculty salaries in the United States, 1969-1989. Applied Economics, 28, 857-864.

Bonebright, C.A., Clay, D.L., \& Ankemann, R.D. (2000) The relationship of workaholism with work-life conflict, life satisfaction and purpose in life. Journal of Counseling Psychology, 47, 4769-477.

Buelens, M., \& Poelmans, S.A.Y. (2004) Enriching the Spence and Robbins' typology of workaholism: Demographic, motivational and organizational correlates. Journal of Organizational Change Management, 17, 440458.

Burke, R.J. (1991) Early work and career experiences of female and male managers: Reasons for optimism? Canadian Journal of Administrative Sciences, 8, 224-232.

Burke, R.J. (1999) Workaholism in organizations: The role of beliefs and fears. Anxiety, stress and coping, 13, 1-12.

Burke, R.J. (2000) Workaholism in organizations: Concepts, results and future research directions. International Journal of Management Reviews, 2, 1-16.

Burke, R.J (2001) Workaholism in organizations: The role of organizational values. Personnel Review, 30, 637-645.

Burke, R.J., Burgess, Z., \& Oberklaid, F. (2002) Workaholism job and career satisfaction among Australian psychologists. International Journal of Management Literature. 2, 93-103.

Burke, R.J. \& Matthiesen, S. (2004) Workaholism among Norwegian journalists: antecedents and consequences. Stress and Health, 20, 301-368.

Burke, R.J., Richardsen, A.M., \& Martinussen, M. (2004) Workaholism among Norwegian managers: Work and well-being outcomes. Journal of Organizational Change Management, 17, 459-470.

Doyle, C. \& Hind, P. (1998) Occupational stress, burnout and job status in female academics. Gender, Work and Organization, 5, 67-83. 
Fassel, D. (1990) Working ourselves to death: The high costs of workholism, the rewards of recovery. San Francisco, CA: Harper Collins.

Frei, R.L., Racicot, B., \& Travagline, A. (1998) The impact of monochromic and Type A behavior patterns on research productivity and stress. Journal of Managerial Psychology, 14, 374-387.

Gander, J. P. (1997) Gender-based faculty-pay differences in academe: A reduced form approach. Journal of Labor Research, 18, 451-461.

Garfield, C.A. (1987) Peak performers: The new heroes of American business. New York: William Morrow.

Ginther, D. K.,\& Hayes, K. J., (1999) Gender differences in salary and promotion in the humanities. American Economic Review. 89, 397-402.

Gmelch, W. H., \& Burns, J. S. (1994) Sources of stress for academic department chairpersons. Journal of Educational Administration, 32, 79-94.

Grandy, A.A. \& Cropanzo, R. (1999) The conservation of resources model applied to work-family conflict and strain. Journal of Vocational Behavior, 454, 350-370.

Greenhaus, J.H., Parasuraman, S. \& Wormley, W. (1990) Organizational experiences and career success of black and white managers. Academy of Management Journal, 33, 64-86.

Harpaz, I., \& Snir, R. (2003) Workaholism: Its definition and nature. Human Relations, 56, 292-320.

Kanai, A., \& Wakabayashi, M. (2004) Effects of economic environmental changes on job demands and workaholism in Japan. Journal of Organizational Change Management, 17, 537-548.

Kanai, A., Wakabayashi, M., \& Fling, S. (1996) Workaholism among employees in Japanese corporations: An examination based on the Japanese version of the workaholism scales. Japanese Psychological Research, 38, 192-203.

Katzenbach, J.R. (2000) Peak performance. Boston: Harvard Business School Press.

Kiechel, W. (1989a) The workaholic generation, Fortune, April 10, 50-62. 
Kiechel, W. (1989b) Workaholics anonymous. Fortune, August 14, 117-118.

Killinger, B. (1991) Workaholics: The respectable addicts. New York: Simon \& Schuster.

Klaft,, R.P. \& Kleiner, B.H. (1988) Understanding workaholics. Business, 33, $37-40$.

Kofodimos, J. (1993) Balancing Act. San Francisco: Jossey-Bass.

Korn, E.R., Pratt, G.J. \& Lambrou, P.T. (1987) Hyper-performance: The A.I.M. strategy for releasing your business potential. New York: John Wiley.

Lawler, E.E. (2003) Treat people right. San Francisco: Jossey-Bass.

Lee, C., Jamieson, L.F. \& Earley, P.C. (1996) Beliefs and fears and Type A behavior: Implications for academic performance and psychiatric health disorder symptoms. Journal of Organizational Behavior, 17, 151-178.

Locke, E.A. (1976) The nature and causes of job satisfaction. In M. Dunnette (eds) Handbook of Industrial and Organizational Psychology. Chicago: Rand McNally.

Machlowitz, M. (1980) Workaholics: Living with them, working with them. Reading, MA: Addison-Wesley.

McDowell, J. M., Singell, L. D., \& Ziliak, J. P. (1999) Cracks in the glass ceiling: Gender and promotion in the economics profession. American Economic Review, 89, 392-396.

McMillan, H.W., O'Driscoll, M.P. \& Brady, E.C. (2004) The impact of workaholism on personal relationships. British Journal of Guidance \& Counselling, 32, 171-186.

McMillan, L.H.W., \& O'Driscoll, M. (2004) Workaholism and health: Implications for organizations. Journal of Organizational Change Management, 17, 509-519

McMillan, L., O'Driscoll, M.P., \& Burke, R.J. (2003) Workaholism: A review of theory, research and future directions. In C.L. Cooper \& I.T. Robertson (eds) International Review of Industrial and Organizational Psychology. New York: John Wiley, pp. 167-190.

Narayanan, L., Menon, S., \& Spector, P. E. (1999) Stress in the workplace: A comparison of gender and occupations. Journal of Organizational Behavior, 20, 63-73. 
Naughton, T.J. (1987) A conceptual view of workaholism and implications for career counseling and research. The Career Development Quarterly, 35, 180-187.

Oates, W. (1971) Confessions of a workaholic: The facts about work addiction. New York: World.

Oshagbemi, T., (2000) Gender differences in the job satisfaction of university teachers. Women in Management Review, 15, 331-

Ozbilgin, M., \& Healy, G. (2004) The gendered nature of career development of university professors: The case of Turkey. Journal of Vocational Behavior, 64, 358-371.

Porter, G. (1996) Organizational impact of workaholism: Suggestions for researching the negative outcomes of excessive work. Journal of Occupational Health Psychology, 1, 70-84.

Porter, G. (2001) Workaholic tendencies and the high potential for stress among co-workers. International Journal of Stress Management, 8, 147-164.

Quinn, R.P. \& Shepard, L.J. (1974) the 1972-73 Quality of Employment Survey, Ann Arbor, MI: Institute for Social Research, University of Michigan.

Robinson, B.E. (1998) Chained to the desk: A gudiebook for workaholics, their partners and children and the clinicians who treat them. New York: NYU Press.

Russo, J. \& Waters, L. (2006) Workaholic worker type differences in workfamily conflict: the moderating role of supervisor support and flexible work scheduling. Career Development International, in press.

Schaef, A.W. \& Fassel, D. (1988) The addictive organization. San Francisco, CA: Harper Row.

Schaufeli, W.B., Taris, T.W., \& Bakker, A.B. (2006) Dr. Jekkyl or Mr. Hyde; On the differences between work engagement and workaholism. In R.J. Burke (ed) Research companion to work hours and work addiction. Cheltenham: Edward Elgar in press.

Schor, J.B. (1991) The Overworked American, New York: Basic books. 
Schor, J.B. (2003) The (even more) overworked American. In J. deGraaf (ed.) Take back your time: Fighting over work and time poverty in America. San Francisco: Berrett-Koehler, pp. 6-11.

Scott, K.S. Moore, K.S., \& Miceli, M.P. (1997) An exploration of the meaning and consequences of workaholism. Human Relations, 50, 287-314.

Seybold, K.C., \& Salomone, P.R. (1994) Understanding workaholism: A view of causes and counseling approaches, Journal of Counseling and Development, 73, 4-9.

Smith, D. B. \& Plant, W. T. (1982) Sex differences in the job satisfaction of university professors. Journal of Applied Psychology, 67, 249-251.

Snir, R., \& Harpaz, I. (2004) Attitudinal and demographic antecedents of workaholism. Journal of Organizational Change Management, 17, 520-536.

Spence, J.T. \& Robbins, A.S. (1992) Workaholism: Definition, measurement, and preliminary results. Journal of Personality Assessment, 58, 160178.

Sprankle, J.K. \& Ebel, H. (1987) The workaholic syndrome. New York: Walker Publishing.

Spruel, G. (1987) Work fever. Training and Development Journal, 41, 41-45.

Taris, T., Schaufeli, W.B., \& Verhoeven, L.C. (2004) Workaholism in the Netherlands: Measurement and implications for job strain and worknonwork conflict. Applied Psychology: An International Review, 53, 3760 .

Waddell, J.R. (1993) The grindstone. Supervision, 26, 11-13 
Figure 1

Research Framework

\section{$\underline{\text { Predictors }}$}

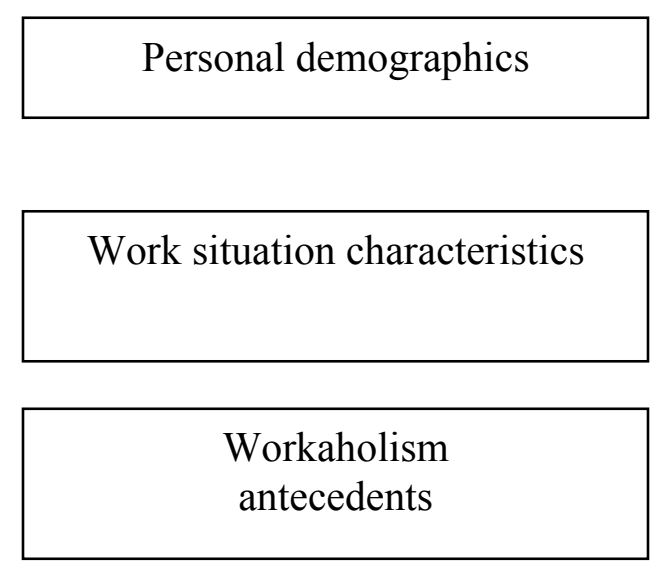

Workaholism components

\section{$\underline{\text { Outcomes }}$}

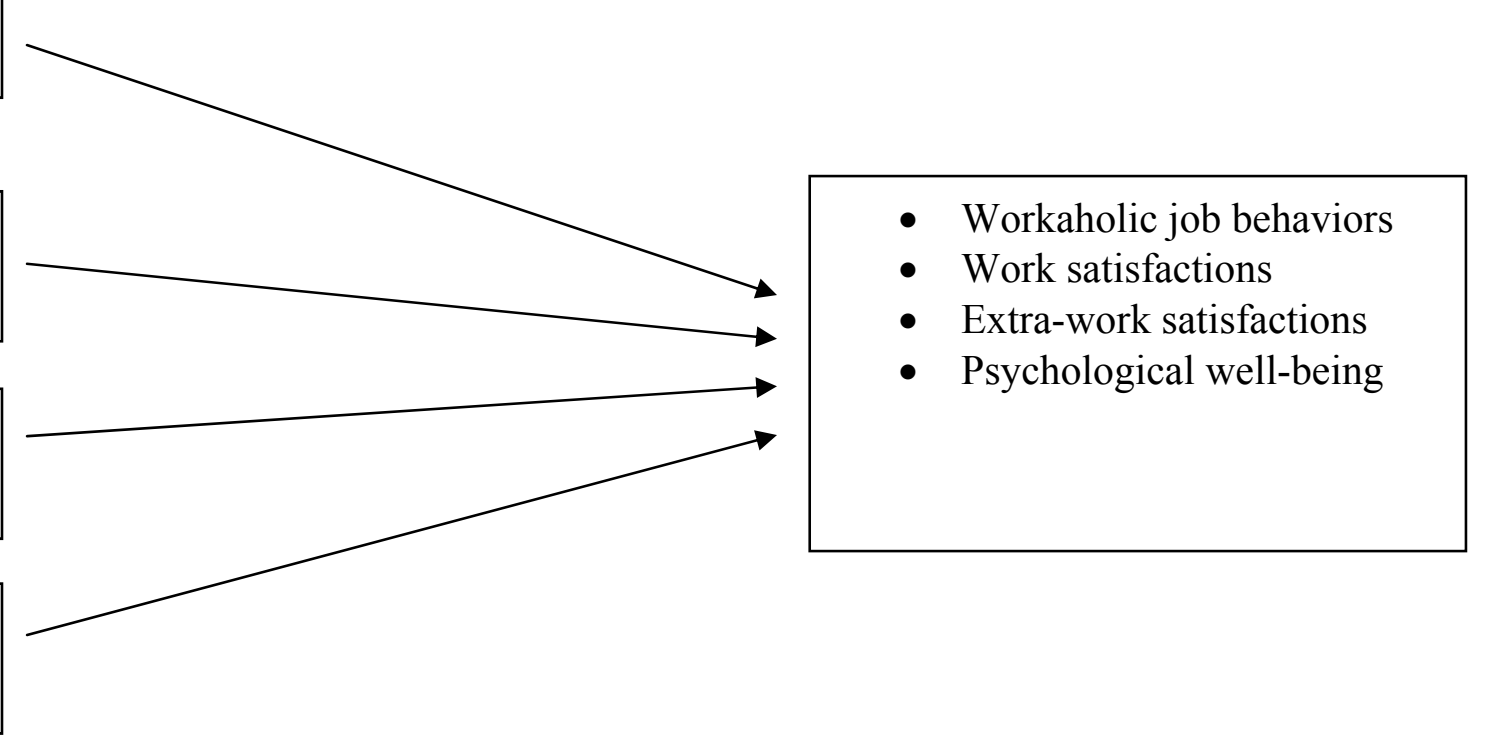


Table 1

Demographic Characteristics

\begin{tabular}{|c|c|c|c|c|c|}
\hline Age & $\underline{\mathrm{N}}$ & $\underline{\%}$ & Gender & $\underline{\mathrm{N}}$ & $\%$ \\
\hline$\overline{20-25}$ & -14 & $3 . \overline{4}$ & $\overline{\text { Male }}$ & $\overline{243}$ & $59 \overline{.6}$ \\
\hline $26-30$ & 90 & 22.1 & Female & 165 & 40.4 \\
\hline $31-35$ & 93 & 22.8 & & & \\
\hline $36-40$ & 89 & 21.8 & Length of Marriage & & \\
\hline \multirow[t]{2}{*}{41 and above } & 122 & 29.9 & $1-5$ years & 72 & 24.4 \\
\hline & & & $6-10$ years & 74 & 25.1 \\
\hline Marital status & & & $11-15$ years & 63 & 21.4 \\
\hline Married & 294 & 71.9 & 16 and above & 86 & 29.1 \\
\hline \multirow[t]{2}{*}{ Single } & 115 & 28.1 & & & \\
\hline & & & Work Status & & \\
\hline Children & & & $\overline{\text { Full time }}$ & 209 & 51.1 \\
\hline$\overline{0}$ & 164 & 40.1 & Contract & 200 & 48.9 \\
\hline 1 & 104 & 25.4 & & & \\
\hline 2 & 107 & 26.2 & Title/level & & \\
\hline 3 & 31 & 2.6 & $\overline{\text { Professor }}$ & 57 & 13.9 \\
\hline \multirow[t]{2}{*}{4} & 3 & .7 & Associate Prof. & 33 & 8.1 \\
\hline & & & Assistant Prof. & 132 & 32.3 \\
\hline Teaching Hours & & & Doctor & 28 & 6.8 \\
\hline$\overline{1-5}$ & 54 & 13.2 & Lecturer & 159 & 38.9 \\
\hline $6-10$ & 84 & 20.5 & & & \\
\hline $11-15$ & 82 & 20.0 & Worked Continuously & & \\
\hline $16-20$ & 85 & 20.8 & Yes & 346 & 84.6 \\
\hline 21 or more & 104 & 25.4 & No & 63 & 15.4 \\
\hline Administrative Duties & & & Worked Part time & & \\
\hline$\overline{\text { Yes }}$ & 155 & 38.1 & $\overline{\text { Yes }}$ & 109 & 26.8 \\
\hline No & 252 & 61.9 & No & 298 & 73.2 \\
\hline University tenure & & & Job Tenure & & \\
\hline $1-5$ years & 163 & 39.9 & $\overline{1-5 \text { years }}$ & 268 & 65.5 \\
\hline $6-10$ & 113 & 27.6 & $6-10$ & 100 & 24.4 \\
\hline $11-15$ & 68 & 16.6 & $11-15$ & 23 & 5.6 \\
\hline 16 or more & 65 & 15.9 & 16 or more & 18 & 4.4 \\
\hline Gross Monthly Salary 2003 & & & Gross Monthly Salary 2004 & & \\
\hline$\$ 700$ US or less & 204 & 49.9 & $\$ 700$ US or less & 141 & 34.5 \\
\hline$\$ 700-1000$ & 107 & 26.2 & $\$ 701-1000$ & 136 & 33.3 \\
\hline$\$ 1001-1400$ & 49 & 12.0 & $\$ 1001-1400$ & 49 & 12.0 \\
\hline$\$ 1401$ and above & 49 & 12.0 & $\$ 1401$ and above & 83 & 20.3 \\
\hline
\end{tabular}


Table 2

Predictors of Workaholic Job Behaviors

$\underline{\text { Workaholic Job Behaviors }}$

Job involvement ( $\mathrm{N}=385)$

Personal demographics

Work situation characteristics

Antecedents

Workaholism Components

Work enjoyment (.56)

Driven (.29)

Work involvement (.09)

Time to job $(\mathrm{N}=357)$

Personal demographics

Work situation characteristics

Antecedents

Org. values (.09)

Workaholism Components

Driven (.44)

Work enjoyment (.27)

Work involvement (.18)

$\underline{\text { Job stress }}(\mathrm{N}=387)$

Personal demographics

Work situation characteristics

Antecedents

Workaholism components

Driven (.54)

Work enjoyment (-.18)

$\underline{\mathrm{R}} \quad \underline{\mathrm{R}}^{\underline{2}} \quad{\underline{\Delta \mathrm{R}^{2}}}^{\underline{\mathrm{P}}}$

$\begin{array}{llll}.09 & .01 & .01 & \text { NS }\end{array}$

$\begin{array}{llll}.13 & .02 & .01 & \text { NS }\end{array}$

$\begin{array}{llll}.13 & .02 & .00 & \text { NS }\end{array}$

$\begin{array}{llll}.70 & .50 & .48 & .001\end{array}$

.09

.00

NS

$.03 \quad .01$

.71

.04

.46

.001

.03

.10

.21

.54
.50

\section{$\underline{P}$}

S

01 
Table 2 (cont'd)

Predictors of Workaholic Job Behaviors

$\underline{\text { Workaholic Job Behaviors }}$

Perfectionism ( $\mathrm{N}=387)$

Personal demographics

Work situation characteristics

Antecedents

Org. values (.12)

Workaholism Components

Driven (.34)

Work enjoyment (.12)

Nondelegation ( $\mathrm{N}=389$ )

Personal demographics

Work situation characteristics

Antecedents

Workaholism components

Driven (.30)

$\begin{array}{llll}\underline{\mathrm{R}} & \underline{\mathrm{R}}^{2} & \underline{\mathrm{R}}^{2} & \underline{\mathrm{P}} \\ .15 & .00 & .00 & \mathrm{NS} \\ .08 & .01 & .01 & \mathrm{NS} \\ .20 & .04 & .03 & .01 \\ .46 & .21 & .17 & .001\end{array}$

$.08 \quad .01$

$.01 \quad \mathrm{NS}$

$.14 \quad .02$

.17

.33

.03

.11

.01

NS

$.01 \quad \mathrm{NS}$

$.08 \quad .001$ 
Table 3

Predictors of Work Outcomes

$\underline{\text { Work Outcomes }}$

Job satisfaction $(\mathrm{N}=389)$

Personal demographics

Work situation characteristics

Antecedents

Workaholism Components

Work enjoyment (.24)

Career Satisfaction ( $\mathrm{N}=388$ )

Personal demographics

Work situation characteristics

Antecedents

Workaholism components

Work enjoyment (.40)

Career prospects $(\mathrm{N}=388)$

Personal demographics

Work situation characteristics

Antecedents

Workaholism components

Work enjoyment (.24)

Intent to Quit $(\mathrm{N}=389)$

Personal demographics

Work situation characteristics

Antecedents

Beliefs (.26)

Values (.11)

$\underline{\text { Workaholism components }}$
$\underline{\mathrm{R}}$

.08

.12

.14

.26

.11

.16

.20

.43

.11

.16

.17

.28

.24

.25

.36

.38

.14

.01

NS 
Table 4

Predictors of Extra-Work Satisfactions

$\underline{\text { Extra-Work Satisfactions }}$

Family Satisfaction $(\mathrm{N}=384)$

Personal demographics

Work situation characteristics

Antecedents

Beliefs (-,14)

Workaholism Components

Relationship Satisfaction ( $\mathrm{N}=355)$

Personal demographics

Work situation characteristics

Antecedents

Balance (.12)

$\underline{\text { Workaholism components }}$

Work enjoyment (.16)

Community Satisfaction ( $\mathrm{N}=389$ )

Personal demographics

Work situation characteristics

Antecedents

Workaholism components

Work enjoyment (.16)

$\underline{\mathrm{R}} \quad \underline{\mathrm{R}}^{\underline{2}} \quad{\underline{\Delta \mathrm{R}^{2}}}^{\underline{\mathrm{P}}}$

$\begin{array}{llll}.10 & .01 & .01 & \text { NS } \\ .13 & .02 & .01\end{array}$

$.13 \quad .02$

$.01 \quad \mathrm{NS}$

.20

.04

.02

.05

.24

.06

.02

NS

$.12 \quad .01$

.04

.01

.03

NS

.19

.06

.02

NS

.01

.31

.09

.03

.01

.12

.13

.15

.21
.01

.02

.02

.05
.01

.01

.00

.03
NS

NS

NS

.05 
Table 5

Predictors of Psychological Well-Being

Psychological Well-Being

Emotional Satisfaction ( $\mathrm{N}=388)$

Personal demographics

Work situation characteristics

Antecedents

Balance (.16)

Beliefs (-.12)

Workaholism Components

Work enjoyment (-.17)

Physical satisfaction ( $\mathrm{N}=389$ )

Personal demographics

Work situation characteristics

Antecedents

Balance (.13)

Workaholism components

Work enjoyment (-.20)

Psychosomatic Symptoms

Personal demographics

Gender (-.28)

Work situation characteristics

Antecedents

Beliefs (.17)

$\underline{\text { Workaholism components }}$

$\underline{\mathrm{R}} \quad \underline{\mathrm{R}}^{\underline{2}} \quad{\underline{\Delta \mathrm{R}^{2}}}^{\underline{\mathrm{P}}}$

$\begin{array}{llll}.11 & .01 & .01 & \text { NS }\end{array}$

$\begin{array}{llll}.12 & .01 & .00 & \text { NS }\end{array}$

$\begin{array}{llll}.25 & .06 & .05 & .001\end{array}$

.30

.09

.03

.05

$.08 \quad .01$

.01

.04

.00

NS

.11

.19

.26

.07

.03

NS

.05

$.03 \quad .01$

.37

.14

.14

.001

.38

.14

.17

.00

NS

.41

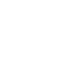

.42

.18

.01

NS 